\title{
Chemical profiling of two aromatic weeds, Cyatbocline purpurea and Blumea lacera
}

\author{
Digambar Nabhu Mokat ${ }^{1 *}$, Sarika Daulatrao Torawane', \\ Yogesh Chandrakant Suryawanshi²
}

'Department of Botany, Savitribai Phule Pune University, Pune-411007, Maharashtra, India, ${ }^{2}$ Department of Biotechnology, Savitribai Phule Pune University, Pune-411007, Maharashtra, India

Received: May 25, 2020 Revised: November 11, 2020 Accepted: December 01, 2020 Published: December 17, 2020

*Corresponding Author: Digambar Nabhu Mokat

E-mail:parimalsai@gmail.com

\begin{abstract}
In the present investigation chemical constituents of Cyathocline purpurea (Buch.-Ham. ex D.Don) Kuntze and Blumea lacera (Burm.f.) DC. (Family-Compositae) were studied by using gas chromatography coupled with mass spectrometry (GC/MS). These two weeds are small herbs and well known for their potent medicinal properties. Total 17 and 27 compounds were identified from C. purpurea and B. lacera respectively. The major constituents in both the extracts were pentadecanoic acid, 14- methyl-, methyl ester (30.56\%), cis-phytol $(21.26 \%), \alpha$-cadinol $(7.87 \%), \gamma$-cadinene $(7.13 \%)$, neophytadiene $(3.81 \%$ ) and $\alpha$-cubebene (1.82\%). GC/MS analysis revealed the presence of various bioactive compounds such as fatty acids, sesquiterpenoids, phenols, etc. in the acetone extracts of both the plants. The identified compounds have various biological activities.
\end{abstract}

KEYWORDS: Cyathocline purpurea, Blumea lacera, GC/MS, Weeds, Sesquiterpenoids

\section{INTRODUCTION}

Cyathocline purpurea (Buch.-Ham. ex D.Don) Kuntze and Blumea lacera (Burm.f.) DC. are commonly found as weed and widely distributed in South Asia, which belongs to the medicinally important Compositae family [1-3]. These plants are small herbs with strong odor and well known for their various medicinal properties which are due to presence of various bioactive compounds [4]. C. purpurea is known for various medicinal properties such as antimicrobial, anthelmintic, anticancer and hypotensive [5-7]. Various phytochemicals of C. purpurea showed anti-inflammatory, antioxidant potential, anti-arthritic activity and stomach relieving properties [8-10]. The plant parts were used in herbal remedy to treat tuberculosis, malaria, bleeding, swelling, rheumatism and a wide range of biological activities including mutagenic, genotoxic, cytotoxic and antitumor actions $[7,11]$. Previously various chemical constituents were reported from this plant such as guaianolide, eudesmanolide, sesquiterpene lactones, isoivangustin and guaianolide [12]. Many sesquiterpenes lactones have shown significant antineoplastic or cytotoxic effects [6].

B. lacera is also valuable medicinal plant in many popular systems of medicine including Ayurveda, Homoeopathy and Unani. There is a heavy demand of different parts (fresh and dry both) of this weed in national and international drug markets [13]. Leaf juice is used as astringent, stimulant, anthelmintic, liver tonic, bleeding piles, diuretic, bronchitis and blood diseases [14,15]. The plant also acts as a good stomachic and antispasmodic activity [16]. It is used in folk medicine for the treatment of cough, bronchitis, dysentery and wound healing potential $[17,18]$.

Despite the fact that, these plants can be best used for its medicinal benefits. No research is available on GC/MS profiling of weed extract of selected plants. The objective of the present study was to assess and generate the phytochemical profile of both the selected medicinally important plants by using gas chromatography techniques.

\section{MATERIAL AND METHODS}

\section{Plant Material and Extract Preparation}

Plant samples $(500 \mathrm{~g})$ were collected from the Western Ghats of Maharashtra during flowering stages (August-September 2018). Plant samples of C. purpurea and B. lacera were collected from Bhimashankar (1904'19.09”N, 73032'8.5”E) and Savitribai Phule Pune University campus (18032'53.9”N, 73049'28.9”E) respectively. The plants were identified and authenticated from the herbarium of Department of Botany, Savitribai Phule Pune 
University, Pune (sweetgum.nybg.org) and assigned voucher number for C. purpurea is Bot/DNM/51/2020 and for B. lacera is Bot/DNM/52/2020.

The plant materials was carefully brought to the laboratory and cleaned with distilled water. The leaves were separated from the plants and spread on a filter paper for shade drying at room temperature $\left(27 \pm 2^{\circ} \mathrm{C}\right)$. The dried leaves were grounded into fine powder using Wiley mill. The powder obtained was passed through $2 \mathrm{~mm}$ sieve. The fine powder $(10 \mathrm{~g})$ mixed in $100 \mathrm{ml}$ of acetone (extract has been repeated thrice) and kept in shaker overnight at $25^{\circ} \mathrm{C}$ at $60 \mathrm{rpm}$. The sample was filtered using Whatman filter paper no. 1 and the solvent from filtrate extract was removed on rotary vacuum evaporator (RVE) at $35-40{ }^{\circ} \mathrm{C}[19]$. After RVE $5 \mathrm{~g}$ of crude extract was obtained and the obtained crude extract was greenish in colour. The extract was soluble in ethanol, methanol, chloroform and acetone. For GC/MS analysis $10 \mu \mathrm{L}$ of crude extract was dissolved in $1 \mathrm{~mL}$ of acetone was used. Each experiment was performed in triplicate and mean was calculated.

\section{Chromatographic Analysis}

For preliminary screening of phytochemicals, acetone extracts of both the plants were subjected to GC/MS. GC was done by using Agilent 7890B while MS on Agilent 5977A MSD. The HP- $5 \mathrm{~ms}$ capillary column $(30 \mathrm{~m} \times 0.25 \mathrm{~mm} \times 25 \mu \mathrm{m})$ was used for the sample analysis. Helium $(99.999 \%)$ was used as a carrier gas at a flow rate of $1 \mathrm{~mL} / \mathrm{min}$. The temperature for GC/ MS analysis was as follows: the injector temperature was kept at $250^{\circ} \mathrm{C}$, the initial temperature in oven was kept at $50^{\circ} \mathrm{C}$ for 3 minute and was increased at a rate of $5^{\circ} \mathrm{C}$ per minute until $175^{\circ} \mathrm{C}$. This temperature was maintained for 2 minute, with a total time of analysis of $30 \mathrm{~min}$. MS data were recorded at $70 \mathrm{eV}$ with a mass range of $\mathrm{m} / z$ of $45-600 \mathrm{amu}$. Single quadrupole mass spectrometer detector $\left(150^{\circ} \mathrm{C}\right)$ was used in MS analysis. The information generated in GC/MS was used for quantification of compounds. For this purpose, an external standard method was used $[20,21]$.

\section{Identification of Compounds}

The compounds were identified by the comparison of retention indices and mass spectra of most of the compounds with those of authentic compounds available in the database of National Institute Standard and Technology (NIST) and Wiley libraries. The identification was further supported by the calculation of their retention indices (RI) under identical experimental conditions using $n$-alkanes $(\mathrm{Cl} 0$ - $\mathrm{C} 40)$ and the calculated indices were then compared to those reported in the literature [22]. The assignments made were further confirmed by co-injection of authentic samples (Sigma-Aldrich) of the identified compounds, wherever possible [23].

\section{RESULTS AND DISCUSSION}

Preliminary analysis of phytochemicals revealed the presence of metabolites of diverse chemical nature in both the plant extracts. Among the 17 compounds identified in C. purpurea extract, the major compounds are pentadecanoic acid, 14-methyl-, methyl ester (30.56\%), methyl oleate (9.56\%), methyl stearate (9.15\%), 2',5'-dimethoxypropiophenone (8.64\%), $\alpha$-cadinol (7.87\%), along with some significant important compounds such as $\alpha$-cubebene $(2.69 \%), \alpha$-cadinene (1.98\%), $\delta$-cadinene $(1.98 \%)$, nonadecanoic acid (1.84\%), $\beta$-cubebene $(1.62 \%), \gamma$-cadinene $(0.98 \%)$ are abundantly present (Table 1 and Figure 1$)$.

Whereas in B. lacera extract total 27 compounds were identified by GC/MS. The major constituents are cis-phytol $(21.26 \%), 13$-octadecenoic acid $(7.64 \%)$, $\gamma$-cadinene $(7.13 \%)$, 2- methyldocosane $(6.42 \%)$, bis (2-ethylhexyl) phthalate $(5.02 \%)$, trans-phytol $(4.45 \%)$, neophytadiene $(3.81 \%)$ beside

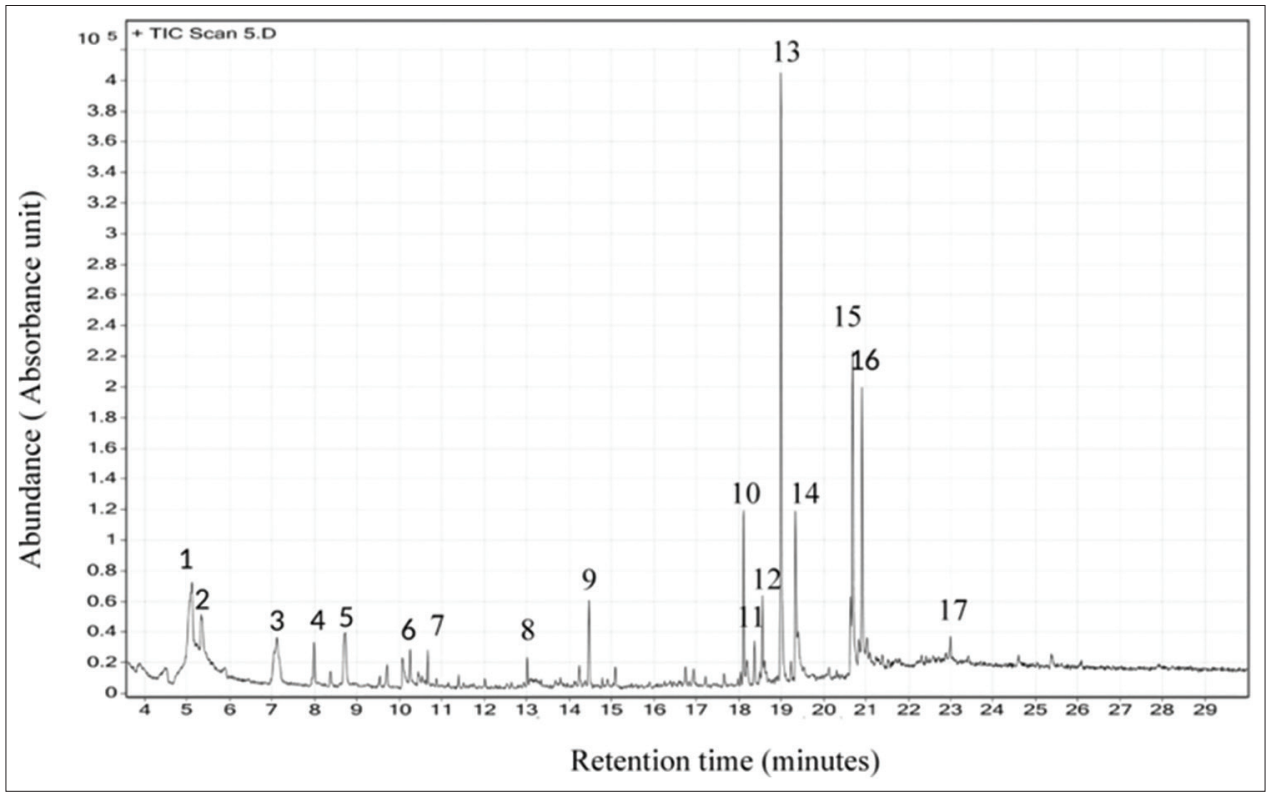

Figure 1: Gas chromatogram of $C$. purpurea extract 
Table 1: Chemical composition of $C$. purpurea extract

\begin{tabular}{|c|c|c|c|c|c|c|}
\hline No & Common name & RT & $\mathrm{RI} \mathrm{a}$ & $\mathrm{RI} \mathrm{b}$ & $\%$ & Identification \\
\hline 1. & $\alpha$-Cubebene & 5.10 & 1345 & 1348 & 2.69 & MS, RI, CI \\
\hline 2. & $\beta$-Cubebene & 5.34 & 1388 & 1387 & 1.62 & MS, RI \\
\hline 3. & Citronellol acetate & 7.11 & 1354 & 1357 & 0.75 & MS, RI \\
\hline 4. & 2'-Nitroacetophenone & 8.11 & 1361 & 1361 & 0.66 & MS, RI \\
\hline 5. & 2,6-Di-Tert-butylphenol & 8.71 & 1444 & 1443 & 0.82 & MS, RI \\
\hline 6. & $\gamma$-Cadinene & 10.14 & 1512 & 1510 & 0.98 & MS, RI \\
\hline 7. & $\delta$-Cadinene & 10.73 & 1522 & 1516 & 1.98 & MS, RI \\
\hline 8. & $\alpha$-Cadinene & 13.04 & 1538 & 1541 & 1.98 & MS, RI \\
\hline 9. & $\alpha$-Cadinol & 14.46 & 1628 & 1626 & 7.87 & MS, RI \\
\hline 10. & $2^{\prime}, 5^{\prime}$-Dimethoxypropiophenone & 18.01 & 1658 & 1658 & 8.64 & MS, RI \\
\hline 11. & Octadecane & 18.30 & 1800 & 1800 & 1.92 & MS, RI, CI \\
\hline 12. & Diisobutyl phthalate & 18.47 & 1868 & 1871 & 5.48 & MS, RI \\
\hline 13. & Pentadecanoic acid, 14-methyl-, methyl ester & 19.01 & 1884 & 1884 & 30.56 & MS, RI \\
\hline 14. & Pentadecanoic acid, 14-methyl-, methyl ester & 19.37 & 1884 & 1884 & 8.84 & MS, RI \\
\hline 15. & Methyl oleate & 21.66 & 2085 & 2082 & 9.56 & MS, RI, CI \\
\hline 16. & Methyl stearate & 21.83 & 2128 & 2130 & 9.15 & MS, RI,CI \\
\hline \multirow[t]{10}{*}{17.} & Nonadecanoic acid & 23.10 & 2236 & 2236 & 1.84 & MS, RI \\
\hline & Fatty acids+esters & 59.95 & & & & \\
\hline & Sesquiterpenes hydrocarbon & 9.25 & & & & \\
\hline & Oxygenated sesquiterpenes & 8.62 & & & & \\
\hline & Aromatic acid & 5.48 & & & & \\
\hline & Ketone & 9.3 & & & & \\
\hline & Alkanes & 1.92 & & & & \\
\hline & Phenols & 0.82 & & & & \\
\hline & Oxygenated monoterpenes & 0.75 & & & & \\
\hline & Total & 96.09 & & & & \\
\hline
\end{tabular}

$\mathrm{RT}=$ Retention Time, $\mathrm{RI}^{\mathrm{a}}=$ Retention indices relative to $\mathrm{C} 10-\mathrm{C} 40 \mathrm{n}$-alkanes on $\mathrm{HP}-5 \mathrm{~ms}$ Column, $\mathrm{RI}^{\mathrm{b}}=$ Retention indices reported in the literature (Adams, 2007), \%= percentage composition of each compound, MS= mass spectrum of the respective compounds from the NIST and Wiley Library, $\mathrm{RI}=$ Reported retention indices, $\mathrm{CI}=$ Co-injection with the authentic sample. *Fatty acids +esters (Sr. No. 13,14,15,16,17), Sesquiterpenes hydrocarbon (Sr. No. 1,2,6,7,8), Oxygenated sesquiterpenes (Sr. No. 9), Aromatic acid (Sr. No. 12), Ketone (Sr. No. 4,10), Alkanes (Sr. No. 11), Phenols (Sr. No. 5), Oxygenated monoterpenes (Sr. No.3)

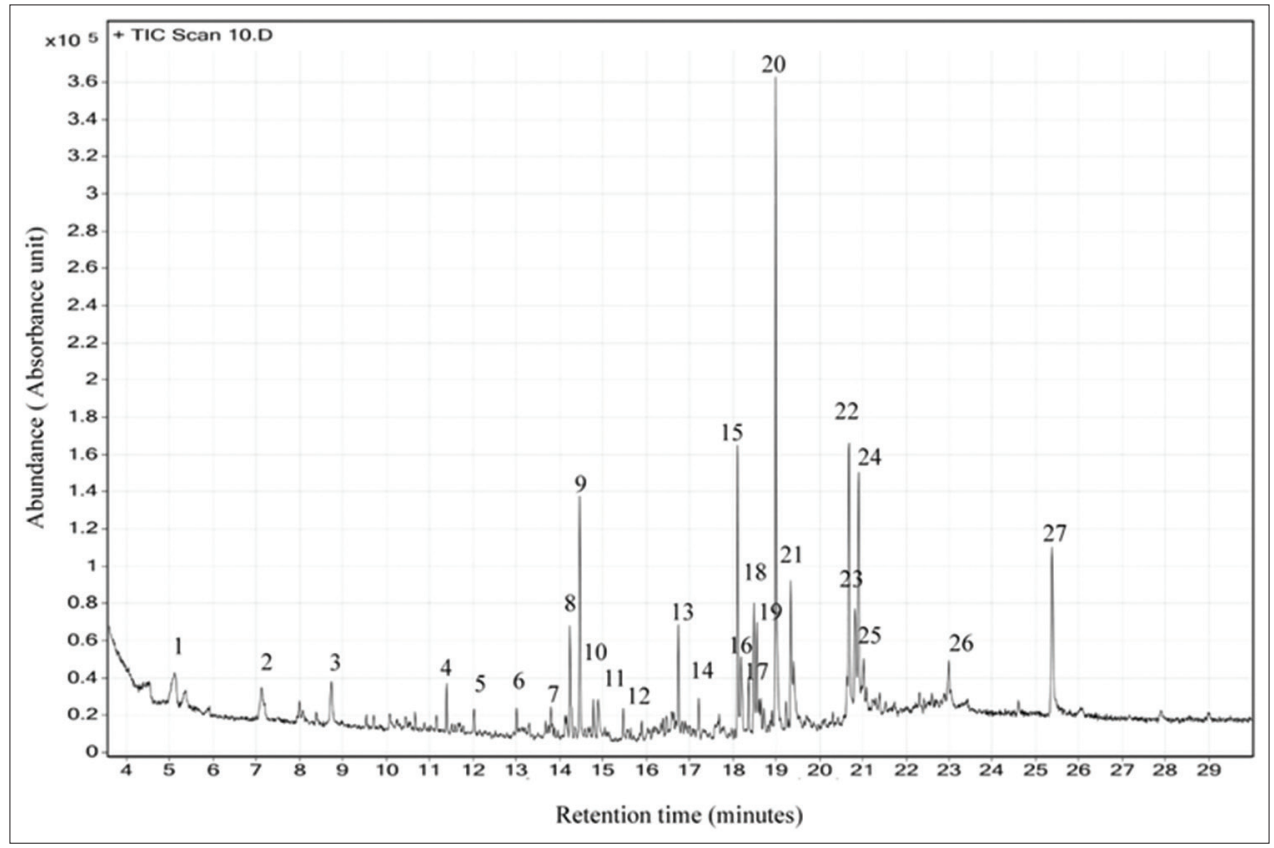

Figure 2: Gas chromatogram of $B$. lacera extract

this some important compounds such as 2,4-di-tert-butylphenol (3.81\%), palmitic acid (3.77\%), nonadecane (3.5\%), methyl oleate $(3.48 \%)$, methyl palmitate $(2.78 \%)$, stearic acid $(2.01 \%), \alpha$-cubebene $(1.82 \%)$, octanal $(0.86 \%), \alpha$-copaene $(0.53 \%)$ are profusely extant (Table 1 Figure 1$)$.
The crude extracts of C. purpurea and B. lacera was mainly composed of fatty acids + esters (59.95 and $27.09 \%$ ) followed by sesquiterpenes hydrocarbon (9.25 and $14.48 \%$ ), oxygenated sesquiterpenes (8.62 and $25.71 \%$ ), alkanes (1.92 and $5.14 \%$ ), oxygenated monoterpenes $(0.75$ and $1.33 \%)$, phenols $(0.82$ 
Table 2: Chemical composition of $B$. lacera extract

\begin{tabular}{|c|c|c|c|c|c|c|}
\hline No & Common name & RT & RI a & $\mathrm{RI} \mathrm{b}$ & $\%$ & Identification \\
\hline 1. & Octanal & 5.21 & 1001 & 999 & 0.86 & MS, RI, CI \\
\hline 2. & 2-Isooctanone & 7.22 & 1259 & 1260 & 0.82 & MS, RI \\
\hline 3. & $\alpha$-Cubebene & 8.71 & 1349 & 1350 & 1.82 & MS, RI \\
\hline 4. & Citronellol acetate & 11.49 & 1354 & 1357 & 1.33 & MS, RI \\
\hline 5. & $2^{\prime}$-Nitroacetophenone & 12.10 & 1361 & 1361 & 0.52 & MS, RI \\
\hline 6. & $\alpha$-Copaene & 13.10 & 1378 & 1376 & 0.53 & MS, RI \\
\hline 7. & $\beta$-Caryophyllene & 13.72 & 1442 & 1445 & 0.56 & MS, RI \\
\hline 8. & 2,4-Di-tert-butylphenol & 14.29 & 1502 & 1494 & 3.81 & MS, RI \\
\hline 9. & $\gamma$-Cadinene & 14.46 & 1512 & 1510 & 7.13 & MS, RI \\
\hline 10. & $\beta$-Sesquiphellandrene & 14.71 & 1537 & 1537 & 0.63 & MS, RI \\
\hline 11. & $2^{\prime}, 5^{\prime}$-Dimethoxypropiophenone & 14.86 & 1658 & 1658 & 0.63 & MS, RI \\
\hline 12. & 2-(1-Phenylethyl)phenol & 15.49 & 1721 & 1720 & 0.73 & MS, RI \\
\hline 13. & Neophytadiene & 16.78 & 1830 & 1830 & 3.81 & MS, RI \\
\hline 14. & Diisobutyl phthalate & 17.21 & 1863 & 1868 & 3.1 & MS, RI \\
\hline 15. & Pentadecanoic acid, 14-methyl-, methyl ester & 18.09 & 1877 & 1877 & 7.41 & MS, RI \\
\hline 16. & Nonadecane & 18.22 & 1900 & 1900 & 3.5 & MS, RI, CI \\
\hline 17. & Methyl palmitate & 18.40 & 1902 & 1904 & 2.78 & MS, RI,CI \\
\hline 18. & Palmitic acid & 18.55 & 1964 & 1963 & 3.77 & MS, RI, CI \\
\hline 19. & Methyl oleate & 18.61 & 2103 & 2103 & 3.48 & MS, RI, CI \\
\hline 20. & cis-Phytol & 19.03 & 2114 & 2113 & 21.26 & $\mathrm{MS}, \mathrm{RI}$ \\
\hline 21. & trans-Phytol & 19.30 & 2122 & 2120 & 4.45 & MS, RI \\
\hline 22. & 13-0ctadecenoic acid, methyl ester & 20.69 & 2126 & 2125 & 7.64 & MS, RI \\
\hline 23. & Stearic acid & 20.78 & 2128 & 2130 & 2.01 & $\mathrm{MS}, \mathrm{RI}, \mathrm{CI}$ \\
\hline 24. & 2-Methyldocosane & 20.91 & 2264 & 2265 & 6.42 & MS, RI \\
\hline 25. & Tricosane & 21.13 & 2300 & 2300 & 1.64 & $\mathrm{MS}, \mathrm{RI}$ \\
\hline 26. & Butoxycarbonylmethyl butyl phthalate & 23.12 & 2403 & 2402 & 1.6 & $M S, R I$ \\
\hline \multirow[t]{12}{*}{27.} & Bis(2-ethylhexyl) phthalate & 25.39 & 2550 & 2545 & 5.02 & MS, RI \\
\hline & Fatty acids + esters & 27.09 & & & & \\
\hline & Oxygenated Diterpene & 25.71 & & & & \\
\hline & Sesquiterpenes hydrocarbon & 14.48 & & & & \\
\hline & Aromatic acid & 9.72 & & & & \\
\hline & Fatty acyl & 7.24 & & & & \\
\hline & Alkanes & 5.14 & & & & \\
\hline & Phenols & 4.54 & & & & \\
\hline & Oxygenated monoterpenes & 1.33 & & & & \\
\hline & Ketone & 1.15 & & & & \\
\hline & Aldehyde & 0.86 & & & & \\
\hline & Total & 97.26 & & & & \\
\hline
\end{tabular}

$\mathrm{RT}=$ Retention Time, $\mathrm{RI} \mathrm{I}^{\mathrm{a}}=$ Retention indices relative to $\mathrm{C} 10-\mathrm{C} 40 \mathrm{n}$-alkanes on HP-5ms Column, R $\mathrm{I}^{\mathrm{b}}=\mathrm{Retention}$ indices reported in the literature (Adams, 2007), \%= percentage composition of each compound, MS= mass spectrum of the respective compounds from the NIST and Wiley Library, $\mathrm{RI}=$ Reported retention indices, $\mathrm{CI}=$ Co-injection with the authentic sample. *Fatty acids+esters (Sr. No. 15, 17, 18, 19, 22, 23), 0xygenated Diterpene (Sr. No. 20,25), Sesquiterpenes hydrocarbon (Sr. No. 3, 6, 7, 10, 13), Aromatic acid (Sr. No. 14, 26

and $4.54 \%)$, ketone (9.3 and $1.15 \%)$, fatty acyl $(7.24 \%)$ and aldehyde $(0.86 \%)$ respectively. The majority of both the plants extracts constituents were rich in fatty acids + esters and sesquiterpenoids (Table 1 and 2).

The most important compounds are abundantly present in both the plants extracts are cubebene, cadinene, copaene, cadinol and citronellolacetate. These various sesquiterpenoids are contributing to the medicinal activities such as anticancer [24], antihelicobacter pylori [25], antimicrobial [26-28], antifungal [29,30], antiviral, antioxidents [31], anti-inflammatory and antipyretic activities [25]. Cubebene was first isolated from Piper cubeba berries and abundantly present in various plants such as Hornstedtia havilandii [32], Pinellia ternate [33], Annona glabra L., Annona squamosa L., Annona muricata L., and Annona reticulata L. [34]. It has role in various plant metabolites. The copaene may act as an oviposition promoter in olive fruit fly [35]. Neophytadiene is reported to act as strong bactericidal, antifungal, antipyretic, analgesic, antioxidant and vermifugic activities [36,37]. Phytol showed antimicrobial, anticancer and antidiuretic activity [36-38]. Palmitic acid, stearic acid and nonadecane acid were used in insect pest management [39]. Long-chain fatty acids such as hexadecanoic acid, octadecanoic acid, pentadecanoic acid, etc. have been reported several times over to possess various biological activities including antimicrobial [40].

The present study revealed that the plant extracts used contain diverse phytochemicals of different chemical nature. Many of the compounds having similar chemical nature are reported to be present in other plants extracts and found to have activities against various diseases and can be used as drugs formulations.

\section{CONCLUSION}

The crude extracts of C. purpurea and B. lacera was analysed by GC/MS and the phytochemical constituents were confirmed. Both the weeds contain diverse phytochemicals such as 
sesquiterpenoids, fatty acids and phenols. These compounds may have some biological activities which may be exploited for bioprospecting in future. However, further research in this direction is required. These harmful weeds in agriculture field produce huge biomass which may be utilized as herbal pesticide, fungicide and herbicide. Considering the presence of different secondary metabolites they may be useful for treating disease and disorders which are to be explored.

\section{ACKNOWLEDGEMENT}

The authors are thankful to the authorities of the Savitribai Phule Pune University, Pune for project fund which was supported by the Departmental Research Development Program (DRDP) project.

\section{REFERENCES}

1. Cooke T. The Flora of the Presidency of Bombay, Vol. II. Botanical Survey of India, Calcutta: 1967

2. Almeida MR. Flora of Maharashtra, Vol. 3 (A) Thomas Paul Almeida for Blatter Herbarium, St. Xavier's College: 1996.

3. Singh NP, Lakshminarasimhan P, Karthikeyan S and Prasanna PV. Flora of Maharashtra state-dicotyledons (flora of India series 2). Botanical Survey of India, Calcutta: 2001

4. Torawane SD, Suryawanshi YC, Mokat DN. Control release of functional bioactive compounds for plants. Encapsulation of Active Molecules and Their Delivery System. Elsevier, India: 2020.

5. Joshi RK. Chemical constituents and antibacterial property of the essential oil of the roots of Cyathocline purpurea. Journal of Ethnopharmacology. 2013; 145(2): 621-625.

6. Ma G, Chong L, Li Z, Cheung AH, Tattersall MH. Anticancer activities of sesquiterpene lactones from Cyathocline purpurea in vitro. Cancer Ehemotherapy and Pharmacology. 2009; 64(1): 143-152.

7. Zu-Qiang L, Guo-Yi M, Lei L, Xi-Tai Z. Sesquiterpene lactones from Cyathocline purpurea. Chemical Journal of Chinese UniversitiesChinese. 2006; 27(5): 859-862.

8. Parrotta JA. Healing Plants of Peninsular India. CABI Publication, New York, USA: 2001.

9. Bihani GV, Rojatkar SR, Bodhankar SL. Anti-arthritic activity of methanol extract of Cyathocline purpurea (whole plant) in Freund's completes adjuvant-induced arthritis in rats. Biomedicine and Aging Pathology. 2014; 4(3): 197-206.

10. Tambewagh UU, Kandhare AD, Honmore VS, Kadam PP, Khedkar VM, Bodhankar, SL, Rojatkar SR. Anti-inflammatory and antioxidant potential of Guaianolide isolated from Cyathocline purpurea: Role of COX-2 inhibition. International Immunopharmacology. 2017; 52(1): $110-118$

11. Yu C, Huang T, Ding Z, Gao X, Zhang Z. Encyclopaedia of chinese medicines, chinese medicinal science and technology Press, Beijing: 1993.

12. Hall IH, Lee KH, Mar EC, Starnes CO, Waddell TG. Antitumor agents. 21. A proposed mechanism for inhibition of cancer growth by tenulin and helenalin and related cyclopentenones. Journal of Medicinal Chemistry. 1977: 20(3): 333-337.

13. Oudhia P, Tripathi RS. A useful weed Blumea lacera L.-A review. Indian Journal of Weed Science. 1999; 31(1-2): 108-109.

14. Warrier PK, Nambiar VPK, Ramankutty C, Vaidya SA. Indian medicinal plants, Orient Longman. Chennai (India): 1995.

15. Jahan K, Kundu SK, Bake MA. Evaluation of antimicrobial and cytotoxic activities of the methanolic and petroleum ether extract of Blumea lacera Burm. f. in Bangladesh. Journal of Pharmacognosy and Phytochemistry. 2014; 2(6): 104-108.

16. Hasan MN, Rahman MH, Guo R, Hirashima A. Hypoglycemic activity of methanolic leaf extract of Blumea lacera in Swiss-albino mice. Asian Pacific Journal of Tropical Disease. 2015; 5(1): 195-198.

17. Roy $B$, Amin R, Uddin MN, Islam AT MS, Islam MJ, Halder BC. Leaf extracts of Shiyalmutra (Blumea lacera DC.) as botanical insecticides against lesser grain borer and rice weevil. Journal of Biological
Sciences. 2015: 5(2): 201-204

18. Satyal P, Chhetri BK, Dosoky NS, Shrestha S, Poudel A, Setzer WN Chemical composition of Blumea lacera essential oil from Nepal. Biological activities of the essential oil and (Z)-lachnophyllum ester. Natural product communications. 2015; 10(10): 1749-1750.

19. Torawane SD, Mokat DN. Allelopathic effects of weed Neanotis montholonii on seed germination and metabolism of mungbean and rice. Allelopathy Journal. 2020; 49(2): 151-163.

20. Naik DG, Dandge CN, Rupanar SV. Chemical examination and evaluation of antioxidant and antimicrobial activities of essential oil from Gymnema sy/vestre R. Br. leaves. Journal of Essential Oil Research. 2011; 23(3): 12-19.

21. Shaikh MN, Suryawanshi YC, Mokat DN. Volatile profiling and essential oil yield of Cymbopogon citratus (dc.) stapf treated with rhizosphere fungi and some important fertilizers. Journal of Essential Oil Bearing Plants. 2019; 22(2): 477-483.

22. Adams RP. Identification of essential oil by gas chromatography/mass Spectrometry, $4^{\text {th }}$ ed, Allured Publishing Corporation: Carol Stream, IL, USA: 2007

23. Suryawanshi YC, Mokat DN. Chemical composition of essential oil of Madhuca longifolia var. latifolia (Roxb.) A. Chev. flowers. Journal of Essential Oil Bearing Plants. 2019; 22(4): 1034-1039.

24. Hui LM, Zhao GD, Zhao JJ. $\delta$-Cadinene inhibits the growth of ovarian cancer cells via caspase-dependent apoptosis and cell cycle arrest. International Journal of Clinical and Experimental Pathology. 2015; 8(6): 6046-6056

25. Osorio JR, Dulcey AJC, Mora LE, Andica RAS. Extraction, chemical composition and antimicrobial activity of the essential oils of Pipilongo (Piper tuberculatum) using supercritical carbon dioxide. Revista de Ciencias. 2013; 17(3): 45-56.

26. Gamal El-Din MI, Youssef FS, Ashour ML, Eldahshan OA, Singab ANB. Comparative analysis of volatile constituents of Pachira aquatica Aubl. And Pachiraglabra Pasq., their anti- mycobacterial and antihelicobacter pylori activities and their metabolic discrimination using chemometrics. Journal of Essential Oil Bearing Plants. 2018; 21(6): 1550-1567.

27. Martins CM, Nascimento ED, de Morais SA, de Oliveira A, Chang R, Cunha L, Silva CD. Chemical constituents and evaluation of antimicrobial and cytotoxic activities of Kielmeyera coriacea Mart. \& Zucc. essential oils. Evidence-Based Complementary and Alternative Medicine. 2015: 2015: 1-9.

28. Gonzalez AM, Tracanna MI, Amani SM, Schuff C, Poch MJ, Bach H, Catalan CA. Chemical composition, antimicrobial and antioxidant properties of the volatile oil and methanol extract of Xenophyllum poposum. Natural product communications. 2012; 7(12): 1663-1666.

29. Mikhaeil BR, Maatooq GT, Badria FA, Amer, MM. Chemistry and immunomodulatory activity of frankincense oil. Zeitschrift für Naturforschung C. 2003; 58(3-4): 230-238.

30. Kundu A, Saha S, Walia S, Shakil NA, Kumar J, Annapurna K. Cadinene sesquiterpenes from Eupatorium adenophorum and their antifungal activity. Journal of Environmental Science and Health, Part B. 2013 48(6): 516-522

31. Dursun A, Guler Z, Ozkan D, Konuşkan DB. Identification of volatile compounds (VCs) in the leaves collected from 'Gemlik', 'Halhalı'and 'Sarı Hasebi' olive tree varieties. International Journal of Secondary Metabolite. 2017; 4(3): 195-204.

32. Hashim SE, Sirat HM, Yen KH. Chemical compositions and antimicrobial activity of the essential oils of Hornstedtia havilandii (Zingiberaceae). Natural product communications. 2014; 9(1): 119120.

33. Iwasa M, Iwasaki T, Ono T, Miyazawa M. Chemical composition and major odor-active compounds of essential oil from Pinellia tuber (dried rhizome of Pinellia ternata) as crude drug. Journal of oleo science. 2014; 63 (2): 127-135

34. Thang TD, Dai DN, Hoi TM, Ogunwande IA. Study on the volatile oil contents of Annona glabra L., Annona squamosa L., Annona muricata $\mathrm{L}$. and Annona reticulata L., from Vietnam. Natural product research. 2013; 27(13): 1232-1236.

35. De Alfonso I, Vacas S, Primo J. Role of $\alpha$-copaene in the susceptibility of olive fruits to Bactrocera oleae (Rossi). Journal of agricultural and food chemistry. 2014; 62(49):11976-11979.

36. Abdel-Aal El, Haroon AM, Mofeed J. Successive solvent extraction and GC-MS analysis for the evaluation of the phytochemical constituents of the filamentous green alga Spirogyra longata. The 
Mokat, et al.

Egyptian Journal of Aquatic Research. 2015; 41(3): 233-246.

37. Madhuvanthi C, Santhosh Kumar K, Antony Ceasar S, Valivittan K, Srinivasan K, Tamilselvi A. Antibacterial, antioxidant and antiproliferative activities of solvent extracts of Tiliacora acuminata. International Journal of Pharmaceutical Sciences. 2014; 6(9): 398-403.

38. Raman BV, Samuel LA, Saradhi MP, Rao BN, Krishna NV, Sudhakar M, Radhakrishnan TM. Antibacterial, antioxidant activity and GC-MS analysis of Eupatorium odoratum. Asian Journal of Pharmaceutical and Clinical Research. 2012; 5(2): 99-106.
39. Karmakar A, Malik U, Barik A. Effects of leaf epicuticular wax compounds from Solena amplexicaulis (Lam.) Gandhi on olfactory responses of a generalist insect herbivore. Allelopathy Journal. 2016; 37(2): 253-272

40. Adesanwo JK, Ajayi IS, Ajayi OS, Igbeneghu OA, McDonald AG. Identification of chemical constituents and evaluation of the antibacterial activity of methanol extract and fractions of the leaf of Melanthera scandens (Schum. etThonn.) Roberty. Journal of Exploratory Research in Pharmacology. 2019: 4(3): 31-40. 